\title{
Polityka regionalna a rozwój przemysłu w rejonie slupskim
}

Sygnalizowany już pod koniec lat siedemdziesiątych, kryzys polskiej gospodarki uwidocznił nie tylko niedoskonałości centralnego zarządzania, ale także przyczynił się do późniejszych zmian ustrojowych zapoczątkowanych ustaleniami okrągłego stołu. Sprzyjający klimat polityczny lat przełomu, pozwolił na uruchomienie szeregu reform $w$ tym także reformy o samorządzie terytorialnym!

Pomimo generalnego sukcesu tej reformy, zakres działalności samorządu terytorialnego pozostał przez szereg lat ograniczony do poziomu lokalnego. Wskutek tego przez większość dekady lat dziewięćdziesiątych struktura administracji publicznej w Polsce była skrajnie scentralizowana, bowiem składała się tylko $\mathrm{z}$ dwu poziomów: administracji rządowej oraz administracji samorządowej na poziomie podstawowego poziomu organizacji terytorialnej państwa. Także budżety funkcjonowały jedynie na tych dwóch poziomach administracji publicznej. Nawet działalność wojewódzkich sejmików samorządowych na poziomie wojewódzkim, będących reprezentacją samorządów lokalnych, nie pozwalała mówić o istnieniu samorządu regionalnego. Dlatego uzasadnione były tezy o braku polityki intraregionalnej (Pyszkowski 1992).

W tak trudnych warunkach ustrojowych, wojewodowie (także sejmiki samorządowe) inicjowali prace nad strategiami rozwoju regionalnego w układzie czterdziestu dziewięciu województw. Jak podaje J. Szlachta (2000) proponowane działania cechowała bardzo różna metodologia i horyzont czasowy, lecz co warte podkreślenia, szereg $\mathrm{z}$ nich powstało w wyniku współpracy wszystkich istotnych „aktorów" w regionie, a efekt końcowy prac był przez nich bardzo często sygnowany.

W funkcjonującym do końca 1998 roku województwie shupskim, w którym bardzo ostro zaznaczyła się recesja gospodarcza „okresu przejścia” (Rydz, Jażewicz 1994, Rydz 1999), również podjęto szereg inicjatyw mających na celu określenie strategii rozwoju, mając na uwadze historycznie ukształtowany model gospodarczy. Jednym z jego podstawowych ogniw, będącym wypadkową położenia geograficznego oraz prowadzonej w latach poprzednich polityki gospodarczej jest działalnośc przemysłowa, która (poza rolnictwem) ma niewątpliwy wpływ na charakter regionu słupskiego. Skoro więc przemysł $\mathrm{z}$ gospodarką morską - obok rolnictwa i turystyki - miał w perspektywie strategicznej decydować o obliczu regionu, być jego fundamentem poprzez pełnienie istotnych funkcji gospodarczych i społecznych zasadnym wydaje się zadanie szeregu pytań o to jak władze

\footnotetext{
${ }^{1}$ Ustawa o samorządzie terytorialnym z dnia 8 marca 1990 roku, Dziennik Ustaw nr 16, poz. 95 z późniejszymi zmianami
} 
regionu (województwa) słupskiego postrzegały rozwój przemysłu w okresie transformacji gospodarczej oraz jaki wpływ wywarła prowadzona polityka na zachowanie się przedsiębiorstw przemysłowych, ich otoczenie a także na układy przestrzenne, formowane i funkcjonujące dotąd $w$ innych realiach gospodarczych.

Wprowadzenie nowych zasad gry rynkowej opartych na wolnej konkurencji, szeroko pojętej innowacyjności, otwartości na otoczenie oraz rosnącej efektywności działalności gospodarczej, powinno wymusić na władzach regionalnych zmianę dotychczasowej polityki regionalnej (w tym polityki przemysłowej).

Ale jak wynika z przeprowadzonej analizy, w początkowym okresie transformacji ustroju ekonomicznego w regionie słupskim, podobnie jak i w całej Polsce nie przywiązywano większego znaczenia do kreowania rzeczywistości gospodarczej na poziomie strategicznym. Większość działań miała charakter doraźny, a brak oddolnych inicjatyw oraz bierność władz lokalnych spowodował, iż lata 1990-1991 uznaje się za okres stagnacji.

$\mathrm{Na}$ ten bardzo zachowawczy charakter działań podejmowanych przez władze lokalne, w zakresie funkcjonowania przemysłu, miała wpływ swoista ułomność regionalnej polityki przemysłowej, gdyż działania interwencyjne i odpowiadające im instrumenty wprowadzane były niejako przy okazji usprawniania innych polityk sektorowych.

Na przełomie 1992 i 1993 roku, przystapiono do pierwszych analiz gospodarki regionu. Pierwsze publikowane wyniki analizy regionalnej przygotowanej przez Deloitte \& Touche ukazały się w grudniu 1993 r. Niestety w analizie przeprowadzonej przez tę firmę, brak jest odniesień do miejsca jakie w strukturze gospodarczej i regionalnej mają zajmować przedsiębiorstwa przemysłowe ${ }^{2}$. Tymczasem proces przechodzenia $\mathrm{z}$ gospodarki centralnie sterowanej do gospodarki rynkowej zmienia owo miejsce w sposób dość istotny. Wynika to m.in. z faktu, iż każde przedsiębiorstwo przemysłowe musi samodzielnie ustalać cele $\mathrm{i}$ to na poziomie nie tylko operacyjnym, ale także strategicznym (Zioło 1994).

Adaptacja przedsiębiorstw przemysłowych regionu do nowych warunków gospodarowania, miała więc charakter bardzo zindywidualizowany, czasami tylko doraźny tak jak w spółce „Sławodrzew” w Sławnie (Czapliński 2000), a jej tempo cechowała dynamika skokowa. Brak stanowczej odpowiedzi na pytanie o rolę i miejsce przemysłu w nowej rzeczywistości gospodarczej musiał spowodować, iż jakość zachodzących zmian była niska. Często dochodziło do drastycznych redukcji załóg, dewastacji lub masowej wyprzedaży środków trwałych, jak miało to miejsce na przykład w przemyśle obuwniczym, a zwłaszcza w PZPS „Alka” a także zerwania kontaktów z niektórymi rynkami zbytu.

Mimo to z opublikowanej w 1995 r. oceny przebiegu procesów restrukturyzacji gospodarki województwa słupskiego ${ }^{3}$ wynika, że rok 1992 i 1993 uznaje się za przełomowy w odniesieniu do ilości prowadzonych przekształceń własnościowych (tab. 1).

Zasadniczy zwrot w prowadzonej dotąd polityce, nastąpił w 1994 roku, kiedy to został wypracowany kształt polityki przemysłowej regionu słupskiego w oparciu o koncepcję polityki przestrzennego zagospodarowania kraju. Prace studialne prowadzone m.in. przez Wojewodę Słupskiego oraz Biuro Planowania Regionalnego CUP w Gdańsku, stały się podstawą do sformułowania wstępnej hipotezy badawczej, która zakładała wielofunkcyjny

\footnotetext{
${ }^{2}$ Analiza gospodarki regionu słupskiego, Deloitte \& Touche, Gdańsk, 1993.

${ }^{3}$ Ocena przebiegu oraz prognoza w zakresie procesów prywatyzacyjnych i restrukturyzacyjnych gospodarki województwa słupskiego, 1995, Wydział Gospodarki i przeksztalceń własnościowych Urzędu Wojewódzkiego w Słupsku.
} 
rozwój gospodarczy w oparciu o ekorozwój (Sobczak, Wobalis 1994). Za takim założeniem przemawiały następujące fakty:

- wysoki udział obszarów prawnie chronionych w powierzchni województwa, sięgający $18,6 \%$. W przeliczeniu na jednego mieszkańca wynosi on $3257 \mathrm{~m}^{2} \mathrm{i}$ jest to blisko dwukrotnie więcej niż wynosi średnia krajowa;

- nie zdegradowane środowisko naturalne regionu, brak przemysłu ciężkiego;

- zdecydowana przewaga małych i średnich przedsiębiorstw przemysłowych o niskim stopniu antropopresji.

Tabela 1. Przekształcenia własnościowe w województwie słupskim

\begin{tabular}{|l|r|r|r|r|r|r|r|r|}
\hline \multirow{2}{*}{ Wyszczególnienie } & \multicolumn{7}{|c|}{ Lata } \\
\cline { 2 - 9 } & 1990 & 1991 & 1992 & 1993 & 1994 & 1995 & 1996 & 1997 \\
\hline $\begin{array}{l}\text { Liczba przedsiębiorstw podległych } \\
\text { Wojewodzie Słupskiemu }\end{array}$ & 96 & 130 & 92 & 47 & 38 & 31 & 33 & 32 \\
\hline $\begin{array}{l}\text { Liczba przedsiębiorstw objętych } \\
\text { procesami przekształceniowymi }\end{array}$ & 2 & 9 & 59 & 63 & 24 & 23 & 20 & 11 \\
\hline $\begin{array}{l}\text { Ogłoszona } \\
\text { Upadłość }\end{array}$ & 1 & 2 & 6 & 7 & 7 & 9 & 9 & 5 \\
\hline $\begin{array}{l}\text { Wykreślono z rejestru } \\
\text { przedsiębiorstw państwowych }\end{array}$ & 1 & 1 & 47 & 51 & 9 & 7 & 8 & 2 \\
\hline
\end{tabular}

Źródło: Materiały Urzędu Wojewódzkiego w Słupsku

Przyjęcie polityki gospodarczej, uwarunkowanej ekologicznie miało w pierwszym rzędzie spowodować, obostrzenie i egzekwowanie norm środowiska naturalnego, ale także miało przyczynić się do stworzenia warunków dla rozwoju małych i średnich przedsiębiorstw poprzez system zachęt ekonomicznych $\mathrm{i}$ instytucjonalnych (budowa otoczenia biznesu).

Poza ogólnymi sformułowaniami polityki przemysłowej, koniecznym było znalezienie rozwiązań problemów sektorowych w oparciu o opracowane w 1993 roku przez Ministerstwo Przemysłu i Handlu założeń polityki przemysłowej państwa. To właśnie z tych ustaleń wynikało typowanie do restrukturyzacji branżowej w pierwszej kolejności przemysłu stoczniowego jako sektora strategicznego, oraz przemysłów lekkiego i maszyn rolniczych jako sektorów „wyższej potrzeby”. Należy jednak zadać pytanie, jakie zmiany zachodziły w regionalnej strukturze branżowej przemysłu. Czy w okresie przechodzenia do gospodarki rynkowej nie doszło do jej przemodelowania i w rezultacie do wykształcenia nowych lokomotyw wzrostu.

Na podstawie badań przeprowadzonych przez E. Rydza i I. Jażewicz (1994) ustalono, że w latach 1980-1992 mimo zróżnicowanej dynamiki zatrudnienia, w skali województwa struktura gałęziowa nie uległa zasadniczej przebudowie. Wydaje się jednak, iż dał się już zauważyć niekorzystny proces określany w literaturze jako ,uwstecznianie się produkcji asortymentowej" (Zioło 1997).

Dalsze badania nad funkcjonowaniem struktur przemysłowych przeprowadzonych przez E. Rydza i l. Jażewicz (1997) oraz autora (Czapliński 2000) dowiodły że w latach 1993-1998 zaszły bardzo istotne zmiany, nie tylko w skali mikroekonomicznej, ale również w strukturze gałęziowej przemysłu. 
Zachodzące zmiany uzasadniały pomoc wymienionym powyżej branżom, lecz wydaje się że przyjęty model strukturalny oparty na przemyśle meblarskim oraz przemyśle materiałów budowlanych jako tzw. „lokomotywach wzrostu” okazał się błędem diagnostycznym już w założeniu tzn. w 1993 r. (ryc. 1).

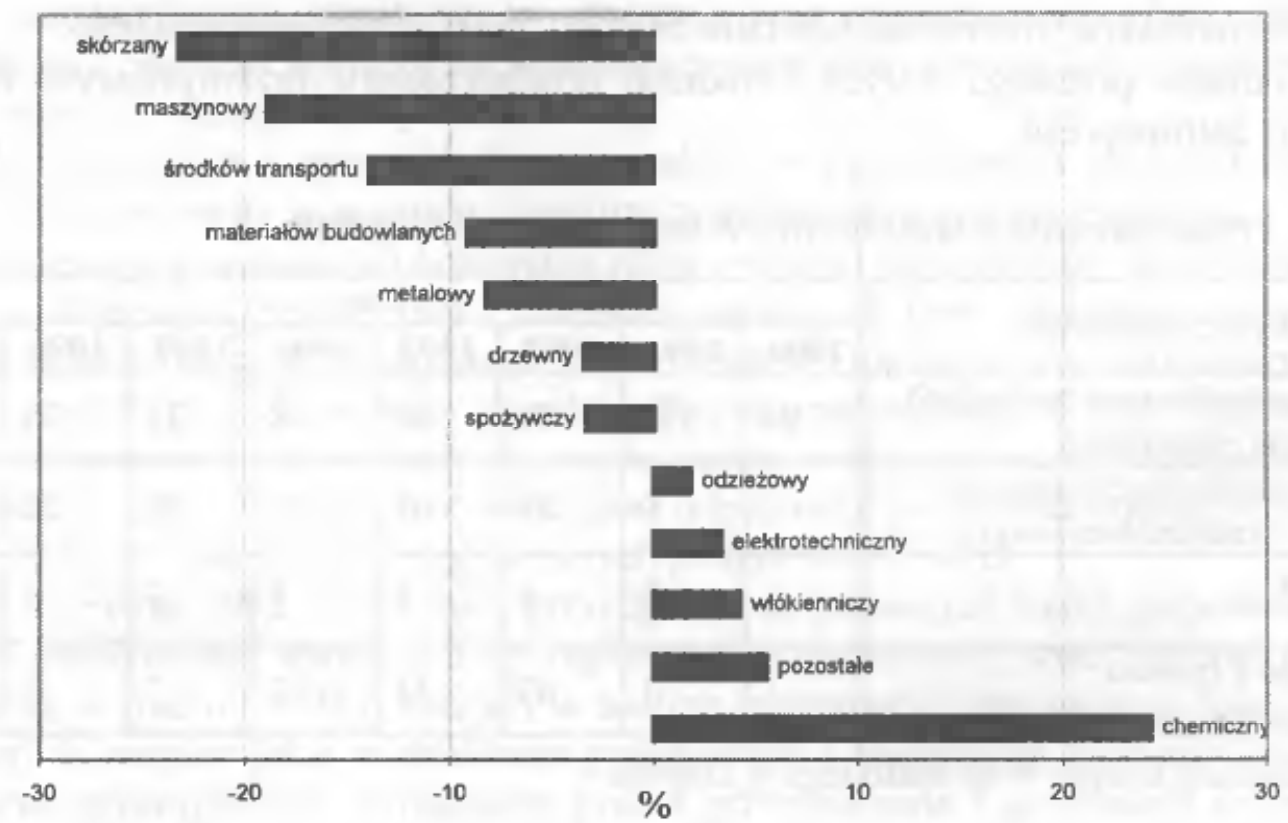

Źródło: Opracowanie własne na podstawie danych z US w Słupsku

Ryc. 1. Rentowność brutto wg gałęzi przemysłu w województwie słupskim w 1993 r.

Uzasadnieniem tej tezy jest obserwowany w latach następnych regres wiodących dotąd branż przemysłu regionu oraz wzrostu „nowych” branż przemysłowych za które uważa się produkcję pojazdów mechanicznych a przede wszystkim produkcję tworzyw sztucznych (tab. 2). Niestety przemysły wzrostowe nie znalazły dostatecznego poparcia wśród elit decyzyjnych i w efekcie na koniec $1998 \mathrm{r}$. i one zanotowały wyhamowanie tempa rozwoju, a wprowadzona od 1 stycznia 1999 r. reforma administracyjna kraju w żaden sposób nie wpłynęła na dotychczasowe status quo.

Znaczącym wydarzeniem rzutującym zwłaszcza na rozważania nad strukturą przestrzenną przemysłu miało w 1994 r. wejście w życie ustawy o specjalnych strefach ekonomicznych $^{4}$.

Problem ten w latach 1990-1993 z uwagi na działania w celu stabilizacji makroekonomicznej a następnie uruchomienia procesów restrukturyzacyjnych na poziomie przedsiębiorstw, zasadniczo nie był podnoszony. Dopiero powstająca w latach 1994-1995 koncepcja programowo - przestrzenna rozwoju przemysłu, po raz pierwszy odniosła się do lokalizacji zakładów przemysłowych, w tym także nowych lokalizacji, przyjmując pas komunikacyjny Słupsk - Lębork za docelowy. Niestety do 1998 r., a więc do końca istnienia województwa słupskiego trzykrotnie zmieniano koncepcję tworzenia struktury przestrzennej

\footnotetext{
${ }^{4}$ Ustawa o specjalnych strefach ekonomicznych z dnia 20 października 1994 roku, Dziennik Ustaw nr 123 , poz. 600
} 
przemysłu, zmieniając nie tylko podejście i metodę wyznaczania obszarów pod inwestycje, ale także kierunek działań, a wszystko to przy mniej lub bardziej widocznej presji lokalnych decydentów.

Tabela 2. Zmiany struktury produkcji i zatrudnienia $w$ działalności produkcyjnej

\begin{tabular}{|c|c|c|c|c|c|c|}
\hline \multirow{3}{*}{ Dzialy według EKD } & \multicolumn{3}{|c|}{ Produkcja sprzedana } & \multicolumn{3}{|c|}{ Przecietne zatrudnienie } \\
\hline & 1993 & 1997 & Dynamika & 1993 & 1997 & Dynamika \\
\hline & \multicolumn{2}{|c|}{$w \%$} & $1993=100$ & \multicolumn{2}{|c|}{$\mathrm{w} \%$} & $1993=100$ \\
\hline $\begin{array}{l}\text { Produkcja pojazdów mechanicznych. } \\
\text { przyczep i naczep }\end{array}$ & 3,9 & 10,2 & 261,5 & 3,0 & 3,8 & 126,7 \\
\hline $\begin{array}{l}\text { Produkcja wyrobów z gumy i two- } \\
\text { rzyw sztucznych }\end{array}$ & 4,8 & 10,5 & 218,8 & 3,8 & 6,3 & 165,8 \\
\hline Produkcja mebli & 5,4 & 6,6 & 122,2 & 8,2 & 8,2 & 100,0 \\
\hline $\begin{array}{l}\text { Produkcja metalowych wyrobów } \\
\text { gotowych, z wyjatkiem maszyn }\end{array}$ & 6.1 & 7,1 & 116,4 & 6,4 & 8,2 & 128,1 \\
\hline $\begin{array}{l}\text { Produkcja wyrobów z pozostałych } \\
\text { surowców niemetalicznych }\end{array}$ & 2,5 & 2,8 & 112,0 & 3,1 & 2,7 & 87,1 \\
\hline $\begin{array}{l}\text { Produkcja drewna i wyrobów z drew- } \\
\text { na oraz ze słomy i wikliny }\end{array}$ & 10,8 & 11,0 & 101,9 & 10,0 & 11,9 & 119,0 \\
\hline $\begin{array}{l}\text { Produkcja pozostałego sprzętu trans- } \\
\text { portowego }\end{array}$ & 4,2 & 4,0 & 95,2 & 4,8 & 4,8 & 100,0 \\
\hline $\begin{array}{l}\text { Produkcja artykułów spożywczych } \\
\text { i napojów }\end{array}$ & 28,2 & 24,9 & 88,3 & 20,3 & 20,6 & 101,5 \\
\hline $\begin{array}{l}\text { Obróbka skóry i produkcja wyrobów } \\
\text { ze skóry }\end{array}$ & 13,2 & 9,7 & 73,5 & 13,4 & 9,4 & 70,1 \\
\hline Produkcja maszyn i urządzeń & 10,4 & 7,1 & 68,3 & 11,0 & 9,9 & 90,0 \\
\hline Pozostale dzialy & 6,3 & 3,9 & 61,9 & 5,8 & 5,2 & 89,7 \\
\hline Produkcja odzieży oraz futrzarstwo & 4,2 & 2,1 & 50,0 & 10,2 & 8,9 & 87,3 \\
\hline
\end{tabular}

Źródło: Opracowanie własne na podstawie danych WUS Słupsk, 1993, 1994, 1997, 1998

Planowany pas inwestycyjny Słupsk-Lębork w 1996 r. zastąpiono tzw. obszarami rozwojowymi. Wydzielono dwa takie obszary: południowy którego centrum stanowić miał Człuchów oraz północny w skład którego miały wchodzić dwa największe miasta regionu Słupsk i Lębork, ale wyraźna koncentracja działalności przemysłowej miała się skupiać w Słupskiej Specjalnej Strefie Ekonomicznej utworzonej w 1997 r. W tym duchu realizowana była także partnerska strategia rozwoju województwa słupskiego, którą ukończono na rok przed likwidacją województwa, pozostawiając prace nad jej realizacją na etapie planowania W 1998 r. pojawiła się jednak nowa koncepcja rozwoju przemysłu w oparciu o korytarze funkcjonalne z których trzy miały uwzględniać działalność przemysłową (ryc. 2). Ów projekt miał być pomostem do dalszych prac nad funkcjonowaniem regionu słupskiego w strukturze województwa pomorskiego. Jednakże wprowadzenie od 1 stycznia 1999 r. reformy administracyjnej kraju unaoczniło, że nowa strategia rozwoju województwa pomorskiego, zakłada kształtowanie przestrzeni przemysłowej w oparciu o tzw. korytarze innowacji (ryc. 3). Te zaś choć po części nawiązują do projektu z 1998 r. to jednak nie mają charakteru tranzytowego (poza głównym Lębork - Słupsk). Ich zakończenia na Bytowie i Człuchowie powodują, że izolacji poddane zostaną peryferyjnie położone miasta byłego 
województwa słupskiego takie jak: Czarne, Debrzno oraz Miastko. Jednocześnie wskazywany jest tylko jeden, gdański kierunek powiązań, co przy tak silnej pozycji Trójmiasta może prowadzić do prawdziwego drenażu ekonomicznego i społecznego.

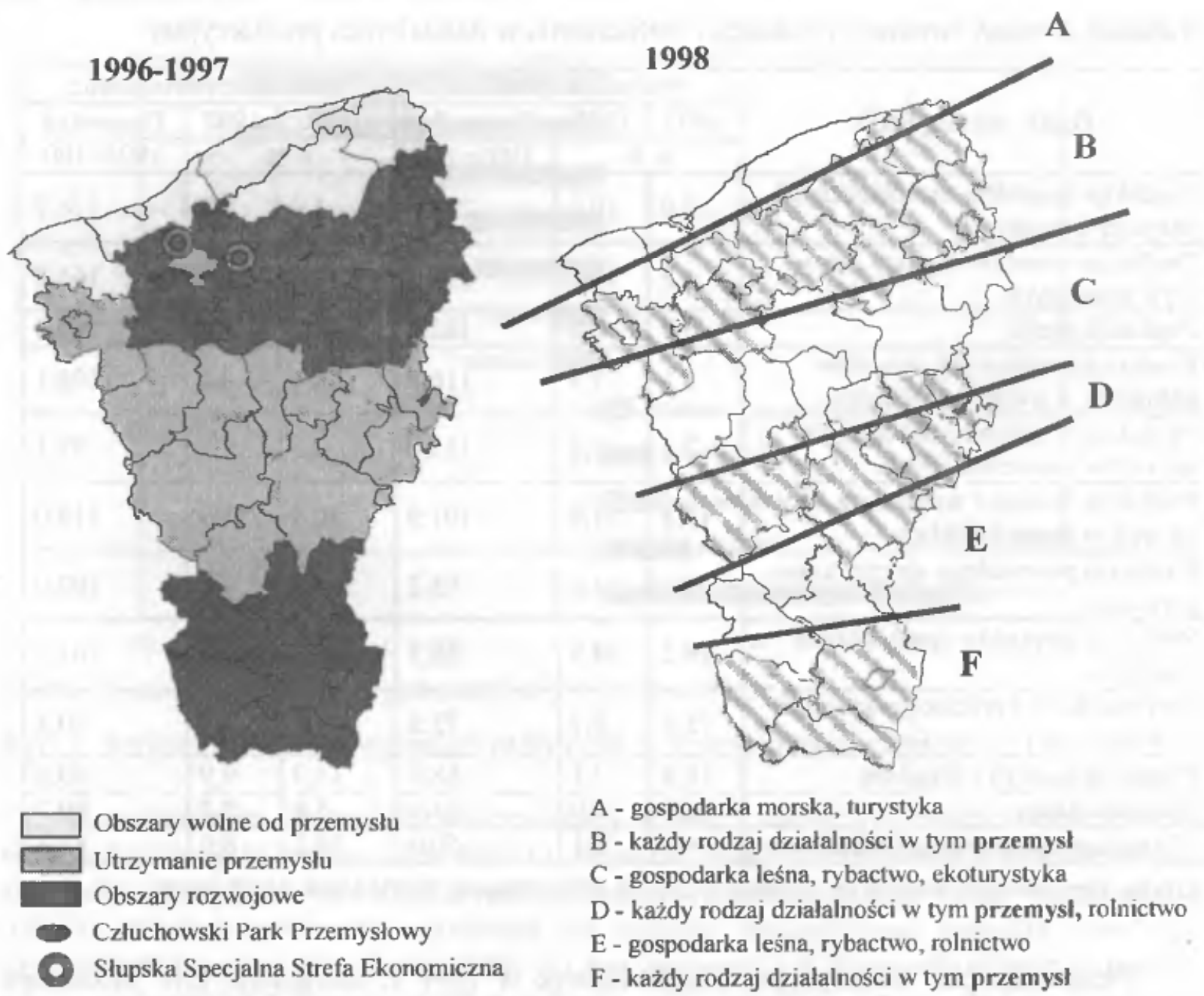

Źródło: Opracowanie własne na podstawie danych UW w Słupsku oraz WBPP w Słupsku

Ryc. 2. Strategia rozwoju przemyshu w strukturze funkcjonalno-przestrzennej regionu shupskiego

Przedstawiony zarys polityki regionalnej w sferze działalności przemysłowej, prowadzonej przez władze regionu (województwa) w latach dziewięćdziesiątych choć nie wyczerpuje tematu, pozwala jednak na zadanie pytania o to jaki wpływ na zachowania w przemyśle miała prowadzona polityka regionalna.

Jak wynika z analizy wielu dokumentów jakie powstały w latach 1990-1998 w instytucjach odpowiadających za rozwój regionalny województwa słupskiego, wiodące zagadnienia restrukturyzacji, związane $\mathrm{z}$ rozwojem przemysłu były traktowana drugorzędnie. Przyczyn takiego stanu należałoby szukać m.in. w dużej złożoności problematyki, ale także w braku komórki administracyjnej, w której zadaniach zawierałaby się owa problematyka.

Zatem brak podstawowych warunków, jakie powinny zostać spełnione przy sprawowaniu procesu decyzyjnego w sposób oczywisty wpłynął na transformację struktur przemysło- 
wych, które zwłaszcza w pierwszych latach zmian systemu gospodarowania (1990-1991) funkcjonowały bez wykorzystania wiedzy dotyczącej nowych realiów gospodarczych.

Jednocześnie powstające po $1993 \mathrm{r}$. analizy gospodarki regionu w sposób bardzo ogólnikowy odnosiły się do przedsiębiorstw przemysłowych, powielając w kolejnych analizach utarte schematy. Tymczasem sama dynamika zmian rynkowych, powodowała opóźnienie wdrożeniowe nie pozwalając zasadniczo na błędy diagnostyczne.

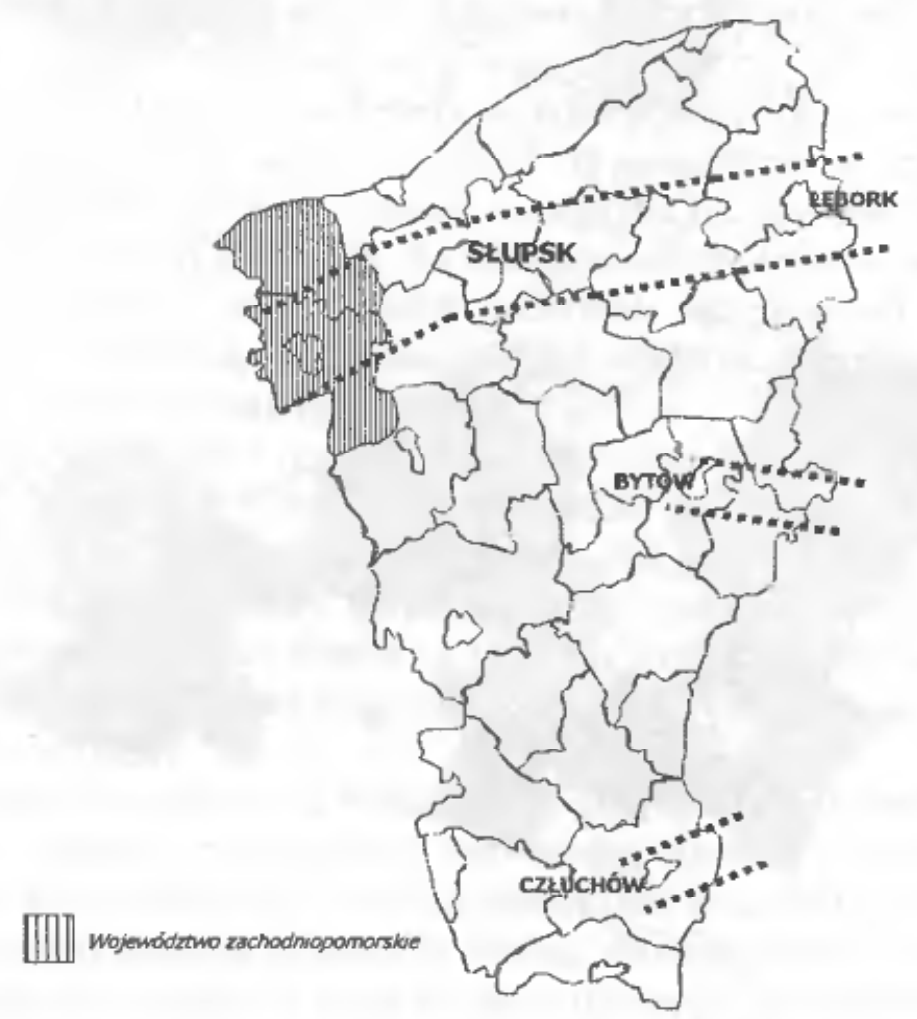

Źródło: Opracowanie własne na podstawie danych z Departamentu Rozwoju Regionalnego i Przestrzennego

Ryc. 3. Koncepcja korytarzy innowacji na obszarze regionu słupskiego według strategii województwa pomorskiego

Jednym z nich powielanym do 1994 r. a odnoszącym się w szczególności do struktury przestrzennej, było założenie, iż przemysł $w$ regionie słupskim przypisany jest $\mathrm{i}$ będzie do miast. Jak wskazują jednak badania autora, już w okresie 1988-1993, bardzo wyraźnie następował proces „wejścia przemysłu” w strefę podmiejską a nawet na obszary dotąd uznawane za rolnicze, przy jednoczesnym procesie inwestycyjnym (za sprawą obcego kapitału) w najbardziej atrakcyjne gminy. Niepokojącym natomiast okazał się wynik z lat 1998-1999, jednoznacznie wskazujący na słabnięcie roli przemysłu jako żródła zarobkowania ludności (ryc. 4). 

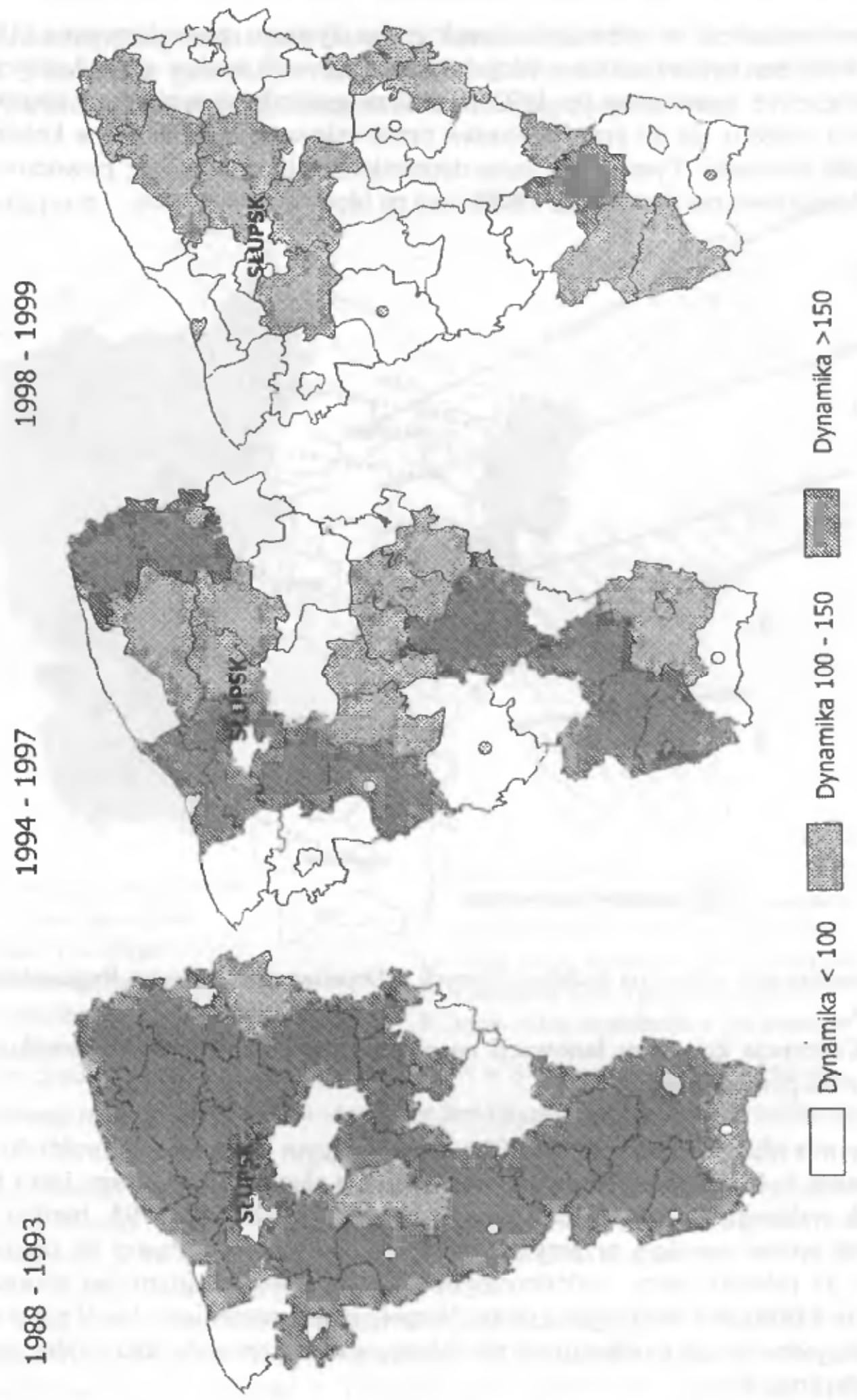

Uwaga: Dynamika zatrudnienia w latach 1993-1997 na postawie sekcji: Działalność produkcyjna Źródło: Opracowanie własne

Ryc. 4. Dynamika zatrudnienia w przemyśle w regionie słupskim 
Odrębnym tematem pozostaje zmiana struktury własnościowej, którą powszechnie uważa się za podstawę reform gospodarczych. Tutaj również przyjęte ścieżki prywatyzacji w bardzo wielu przypadkach okazały się błędne, prowadzące do nieuzasadnionej likwidacji tak jak miało to miejsce w przypadku Zakładów Wytwórczych Aparatury Wysokiego Napięcia „ZWAR” w Lęborku.

Wśród bardzo wielu niedociągnięć, braku kompetencji, ciągle znaczącego wpływu władz centralnych i upolitycznienia bardzo wielu działań (np. lokalizacja Fabryki Frytek „Farm Frites” w Lęborku) władzom regionu udało się stworzyć podwaliny pod nowoczesne otoczenie biznesu. Początki jego tworzenia sięgają przełomu lat 1993/1994 kiedy to w Lęborku a następnie w Słupsku powstawały ośrodki przedsiębiorczości. Oczywiście sam proces choć zainicjowany przez władze odbywał się zasadniczo w oparciu o inicjatywy lokalne, stąd też obecny stan otoczenia biznesu w regionie nie jest tylko zasługą władz, ale przede wszystkim społeczności lokalnych. Za wiodące należy uznać miasta Słupsk, Lębork i Człuchów, gdzie koncentruje się większość jednostek wpierających lub obsługujących małe i średnie przedsiębiorstwa, natomiast słabsze wsparcie posiadają obecnie miasta i gminy wchodzące w skład powiatu bytowskiego (ryc. 5).

Infrastruktura instytucjonalna regionu słupskiego poza tym, że odzwierciedla poziom przedsiębiorczości lokalnej, jest również silnie skorelowane z napływem kapitału zagranicznego, który zazwyczaj wybiera miejsca (miasta lub gminy) lepiej przygotowane do obsługi przedsiębiorstw (ryc. 6). Stąd też wyraźnie rysująca się dominacja trzech ośrodków: miejskich na północy regionu Słupska i Lęborka wraz z obszarem zawartym między nimi i dalej w kierunku Sławna oraz jednego na południu: Człuchowa, który ostro kontrastuje z sąsiadującymi gminami.

Reasumując należy stwierdzić, iż w ciągu dziewięciu lat transformacji w których istniało województwo słupskie, przynajmniej trzy można uważać z rożnych względów za stracone. Dotyczy to wymienianych już dwóch pierwszych oraz roku $1998 \mathrm{r}$. kiedy to świadomość że województwo słupskie przestanie istnieć, spowodowała że władza regionu nie podjęła żadnych ważnych decyzji. A przecież poza niezbędnymi nakładami inwestycyjnymi oraz narzędziami natury prawno-administracyjnej, dla samego procesu restrukturyzacji potrzebny jest odpowiednio długi horyzont czasowy. Utrata jednej trzeciej tak potrzebnego czasu (poza obraniem samej drogi przekształceń) w przypadku przynajmniej kilku przedsiębiorstw regionu spowodowała nieodwracalne zmiany prowadzące często do całkowitej likwidacji jednostki.

$\mathrm{Na}$ początku lat dziewięćdziesiątych, modnym stało się powiedzenie, że brak polityki przemysłowej to najlepsza polityka przemysłowa. Niestety w przypadku regionu słupskiego ta teza okazała się zgubna. 

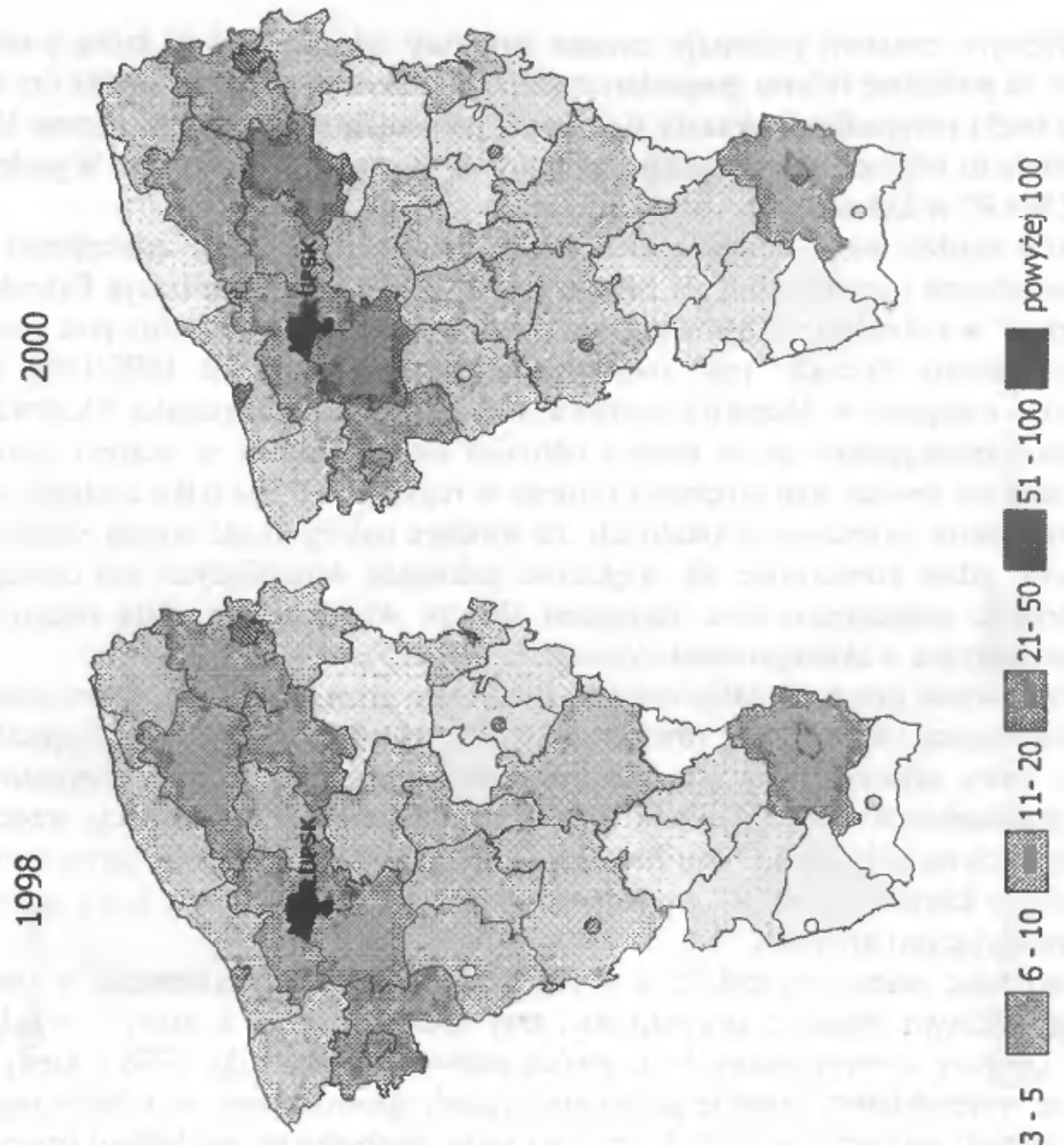

ํำ
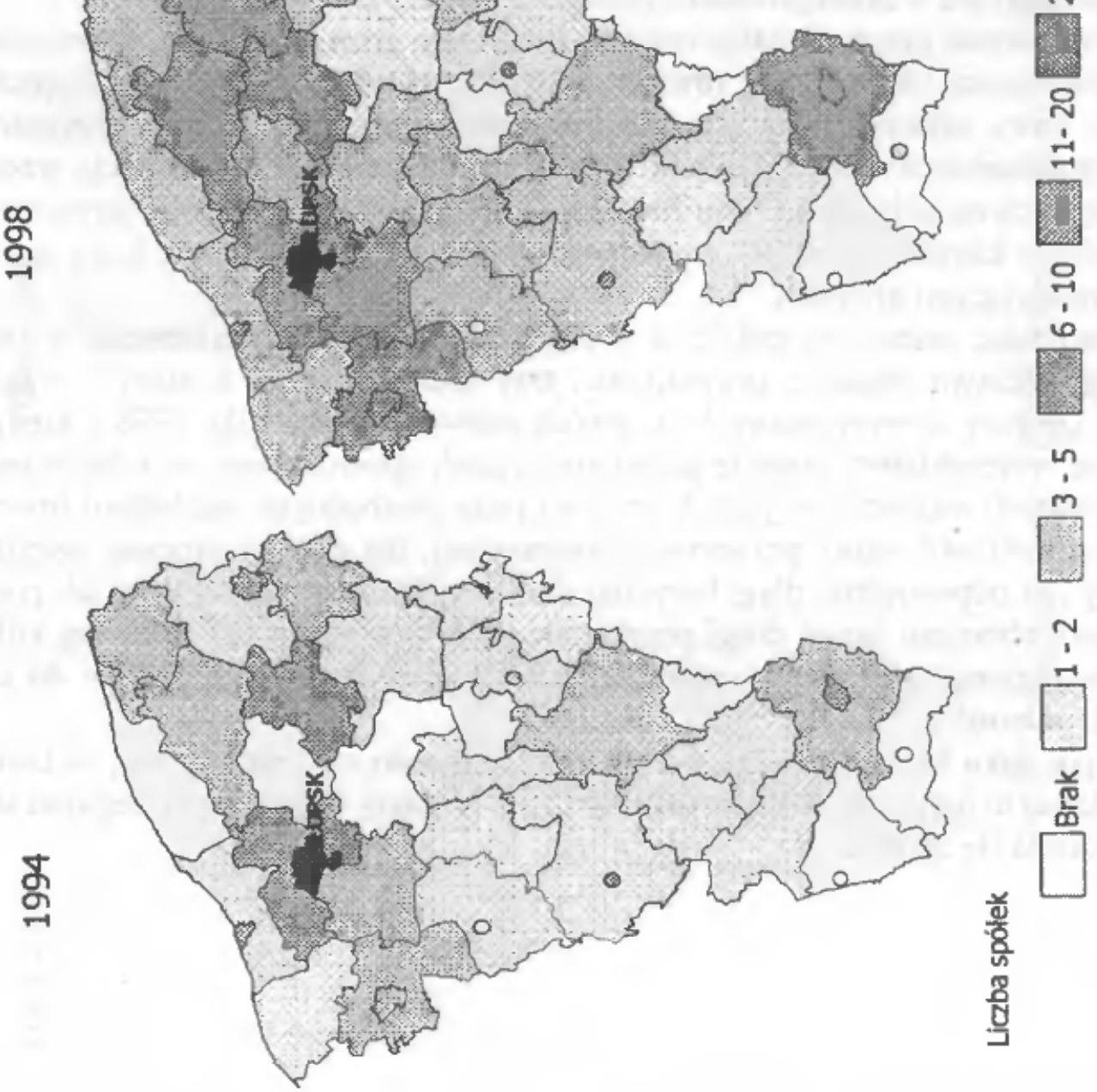

Źródło: Opracowanie własne

Ryc. 5. Spółki prawa handlowego z udziałem kapitału zagranicznego w regionie słupskim 


\section{Literatura}

Czapliński P., 2000, Wlasność komunalna jako jedna z dróg restrukturyzacji przemystu na przykładzie spólki „Slawodrzew" w Stawnie [w:] Środowisko przyrodnicze i gospodarka Dolnego Śląska u progu trzeciego tysiąclecia, Materiały konferencyjne 49 Zjazdu PTG, 20-24 IX 2000 r. Szklarska Poręba, Wyd. Oddział Wrocławski PTG, IG UWr, Wrocław.

Pyszkowski A., 1992, Polityka regionalna $w$ procesie transformacji ustrojowej $w$ Polsce [w:] Polityka regionalna w warunkach gospodarki rynkowej, B. Winiarski (red.), Wyd. PAN, Wrocław - Warszawa - Kraków.

Rydz E., 1999, Spoleczno-ekonomiczne skutki restrukturyzacji gospodarki na przyktadach z Pomorza Środkowego [w:] Przemiany społeczno - gospodarcze struktur przestrzennych w procesie przechodzenia do gospodarki rynkowej, R. Orłowski, Z. Zioło (red.) Wyd. WSZiA, Zamość.

Rydz E., Jażewicz I., 1994, Przemiany struktur przestrzenno-galęziowych przemystu województwa stupskiego $w$ zmieniajq̨cych się warunkach gospodarowania [w:] Zachowanie przestrzenne przemysłu w zmieniających się warunkach gospodarowania, Z. Zioło (red.) Wyd. WSP, Kraków - Warszawa.

Rydz E., Jażewicz I., 1997, Procesy transformacji stupskiego ośrodka przemyslowego $w$ latach 1990-1995 [w:] Problemy transformacji struktur przemysłowych w procesie przechodzenia do gospodarki rynkowej, Z. Zioło (red.), Wyd. Komisja Geografii Przemysłu PTG, WSP Kraków, Warszawa-Kraków.

Sobczak D., 1996, Uwarunkowania rozwoju przemystu [w:] Studium zagospodarowania przestrzennego województwa słupskiego, WBPP, Słupsk.

Sobczak D., Wobalis Z., 1994, Przemyst i gospodarka morska. Diagnoza stanu [w:] Studium zagospodarowania przestrzennego województwa słupskiego, WBPP, Słupsk.

Szlachta J., 2000, Polityka rozwoju regionalnego Polski na przełomie XX i XXI wieku, material powielony.

Urban R., Drożdż J., Bielecki J., 1995, Diagnoza rozwoju przemystu rolno-spożywczego [w:] Studium zagospodarowania przestrzennego województwa słupskiego, WBPP, Słupsk.

Zioło Z., 1994, Zmiany otoczenia przedsiębiorstw przemyslowych $w$ nowych warunkach gospodarowania [w:] Funkcjonowanie przedsiębiorstw przemysłowych w zmieniających się warunkach gospodarowania, Z. Zioło (red.), Wyd. COM, Komisja Geografii Przemysłu PTG, Warszawa - Kraków.

Zioło Z., 1997, Problemy transformacji struktur przemyslowych w procesie przechodzenia do gospodarki rynkowej [w:] Problemy transformacji struktur przemysłowych w procesie przechodzenia do gospodarki rynkowej, Z. Zioło (red.), Wyd. Komisja Geografii Przemysłu PTG, WSP Kraków, Warszawa-Kraków. 